Abant Tıp Dergisi

Editöre Mektup / Cilt 10 Sayı 2 YII 2021
Abant Medical Journal

Letter to Editor / Volume 10 Issue 2 Year 2021

\title{
Endora'da Yaşamak Müziksiz Dans Etmek Gibidir: What's Eating Gilbert Grape? Sağlık Psikolojisi Perspektifinden Bir Film Analizi
}

\section{Living in Endora is Like Dancing Without Music: What's Eating Gilbert Grape? A Film Analysis from the Health Psychology Perspective}

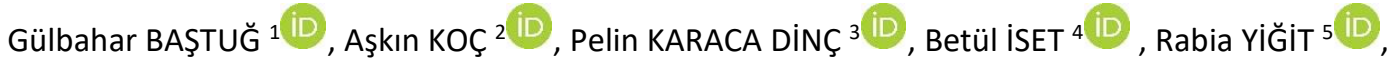

Selma Gül Aksin 6 ii

${ }^{1}$ Ankara Üniversitesi Sağlık Hizmetleri Meslek Yüksekokulu, Keçiören, Ankara, Türkiye

${ }^{2}$ Konutkent Mahallesi, Çankaya, Ankara, Türkiye

${ }^{3}$ Ankara Üniversitesi, Dil ve Tarih-Coğrafya Fakültesi, Psikoloji Bölümü, Ankara, Türkiye

${ }^{4}$ Atatürk Mahallesi Fevzi Çakmak Caddesi Kahramankazan, Ankara, Türkiye

${ }^{5}$ Seyranbağları Mahallesi, Çankaya, Ankara, Türkiye

${ }^{6}$ Irmak Mahallesi, Gaziemir, İzmir, Türkiye

\section{Öz}

Bu makalede özgün adı "What's Eating Gilbert Grape?" olan filmin sağıı psikolojisi açısından incelenmesi amaçlanmıştır. $\mathrm{Bu}$ incelemede filmdeki başrol oyuncuların karakterleri analiz edilmiş, kişilik özellikleri tanımlanmıştır. Otizm spektrum bozukluğu ve entelektüel yeti yitimi tanılarını karşılayabileceği düşünülen Arnie karakteri bu tanılar açısından incelenmiştir. Filmde anne karakteri olarak öne çıkan Bonnie ise obezite rahatsızığından muzdariptir. Bonnie ve Arnie karakterlerinin sağlık problemleri çevresel faktörler, risk faktörleri ve koruyucu faktörler açısından incelenmiştir. Filmdeki diğer karakterlerin duygusal çatışmaları, psikolojik gelişimleri sağlık psikolojisi açısından değerlendirilmiştir. Filmde yer alan konulara baktığımızda, Gilbert'ın aşk hayatı ile ailedeki sorunlar arasındaki çatışmanın, Ellen'in yaşadığı ergenlik sorunlarının, annenin rahatsızlığı nedeniyle evdeki rollerin çocuklara dağılmasının vurgulandığını görmekteyiz. Tüm bu sıkıntılara rağmen filmin sonunda ise karakterlerin kendilerine yeni hayatlar çizdiği görülmektedir.

Anahtar Kelimeler: sağlık psikolojisi, obezite, yas, otizm spektrum bozukluğu, entelektüel yeti yitimi, film analizi

\section{Sayın Editör;}

"Gilbert'in Hayalleri" 1993 yılı Amerika Birleşik Devletleri (ABD) yapımı dramatik bir filmdir. Özgün adı "What's Eating Gilbert Grape?" olan filmi Lasse Hallström yönetmiş, başrollerinde Johnny Depp (Gilbert Grape), Juliette Lewis (Becky) ve Leonardo DiCaprio (Arnie Grape) oynamıştır. Film, Peter Hedges'in aynı isimli

\section{Abstract}

This article aims to examine the movie "What's Eating Gilbert Grape" in terms of health psychology. In this compilation, the characters of the leading actors in the movie were analyzed and their personality traits were defined. Arnie's character, which is thought to meet the diagnoses of autism spectrum disorder and mental retardation, was examined in terms of these diagnoses. Bonnie, who stands out as the mother character in the movie, suffers from obesity. The health problems of the Bonnie and Arnie characters are examined in terms of environmental factors, risk factors and protective factors. The emotional conflicts and psychological developments of the other characters in the film were evaluated in terms of health psychology. When we look at the subjects in the film, we see that the conflict between Gilbert's love life and family problems, Ellen's adolescence problems, and the distribution of roles at home to children due to the mother's illness are emphasized. Despite all these difficulties, at the end of the film, the characters draw new lives for themselves.

Keywords: health psychology, obesity, grief, autism spectrum disorder, mental retardation, film analysis

romanından sinemaya uyarlanmıştır. Manor, Texas'da çekilen filmin müziklerini ise Alan Parker yapmıştır. Endora adında küçük bir yerleşkede Gilbert ve ailesinin yaşantısını konu edinen filmde psikolojinin çeşitli alanlarına yönelik birçok duruma yer verilmektedir. Bu incelemede sırasıyla öne çıkan karakterlerin analizi (karakterlerin kişilik özellikleri, tanıtımı); 
çevresel faktörler, risk faktörleri ve koruyucu faktörler; otizm spektrum bozukluğu (OSB) ve entelektüel yeti yitimi (Arnie karakteri üzerinden tanısal bir tartışma) ve obezite (Bonnie karakteri üzerinden bir analiz) gibi konuların genel bir değerlendirmesi yapılacaktır. Bu doğrultuda çalışmanın amacı gerçek hayat temeline oturtulan "What's Eating Gilbert Grape?" filmindeki karakterleri sağlık psikolojisi perspektifinde incelemek ve bu karakterler üzerinden çeşitli psikopatolojilerin analizini yapmaktır.

Bütüncül perspektifte bir yaklaşım ile karakterler üzerinden yapılacak olan vaka analizlerinin literatüre çeşitli katkılarda bulunacağı düşünülmektedir. Filmleri psikolojik yaklaşımlarla ele almak okuyucunun kuramsal bilgiyi gözünde canlandırmasına, bu bilgilere yönelik gerçek hayatta oluşabilecek örnekleri görmesine katkı sağlamaktadır. Bu yazıda da obezite, OSB, entelektüel yeti yitimi gibi psikolojik rahatsızlıkların klinik açıdan görünümünün nasıl olabileceği bir film üzerinden anlatılmıştır. Film üzerinden ele alınan kavramlar bir çeşit vaka analizi görevi görmektedir. Filmin analiziyle psikolojik rahatsızıkların anlatımı ve ele alınması rahatsızlıkların etiyolojik faktörleri açısından da önemli görülmektedir. Sadece psikolojik rahatsızlıklar değil aile içi etkileşim örüntüleri ve bunun bireyler üzerindeki etkisi filmdeki karakterlerin gelişimiyle ele alınmıştır. Filmler kimi zaman kendi yaşamımızda oluşabilecek zorluk durumlarını da bizlere yansıtabilmektedir. $\mathrm{Bu}$ nedenle de filmleri psikolojik açıdan ele almanın okuyucuya önemli bilgiler sunacağı düşünülmektedir. Bu film analizi ile obezite, OSB ve entelektüel yeti yitimi kavramlarının gerçek hayatta görünümünün nasıl olabileceğini, bireylere verdiği psikolojik yükün nasıl ele alındığını gösterebilmek hedeflenmektedir.

Karakterlerin ve Filmin Geçtiği Yerin Kısaca Tanıtımı
Gilbert Grape babasının ölümünden sonra evde baba rolünü üstlenmiş olan 24 yaşında bir gençtir. Kardeşi Arnie'nin bakımından ve eve gelir sağlamaktan sorumludur. Gilbert'in ailesine sürekli bakım verme sorumluluğu sebebiyle zaman zaman bunalmış ve stresli olduğu görülmektedir.

Bonnie Grape ailenin annesidir. Gününün tamamını aynı kanepede oturarak, yemek yiyerek, televizyon izleyerek ve sigara içerek geçirmektedir. Morbid obezite, depresyon gibi fiziksel ve psikolojik sağlık sorunları mevcuttur. Kocasının intiharından sonra morbid obeziteye doğru ilerleyen öyküsünde yer yer aşırı kilosundan dolayı utanç duyduğu görülmektedir.

Arnie Grape 17 yaşında, gelişimsel ve zihinsel gecikmenin belirgin olduğu, OSB'nda yer alan belirtilerden bazılarını gösteren bir gençtir. Ergenlik döneminde olmasına rağmen, küçük bir çocuğun zihinsel kapasitesine sahiptir.

Amy Grape 35 yaşında, evde anne rolünü üstlenen genç bir kadındır. Ev işlerinin yapılmasında bütün sorumluluğu üstlenmekte ve zamanının çoğunu evde geçirmektedir. Filmin sonunda bir fırından (Des Moines'te) işletmeci olarak teklif alır ve Endora'dan ayrılır.

Ellen Grape ailenin 15 yaşındaki bir üyesidir. Genel olarak yaşantısından memnun olmadığı söylenebilir. Arnie ve Gilbert ile pek iyi anlaşamamaktadır. Ellen da kardeşleri gibi Endora'yı terk etmek ve okul değiştirmek için sabırsızlanmaktadır.

Betty Carver 40 yaşında, evli ve iki çocuk sahibi bir kadındır. Vaktinin çoğunu evinde geçirmekte, kocasıyla ilişkisinde sorunlar yaşamaktadır ve hayatından memnun değildir. Davranışlarına bakıldığında evlilik hayatını seçmekten ve çocuk sahibi olmaktan kaynaklı pişmanlıkları olduğunu söylemek mümkündür. Kocasının bir metrelik bir havuzda ölmesi üzerine kocasını öldürdüğüne dair çevre baskısına dayanamaz ve Endora'yı terk eder. 
Becky 20 yaşında, özgür ruhlu genç bir kadındır. Gezmeyi çok sevmekte, yılda bir kez anneannesi ile birlikte karavanlarıyla Endora'ya gelmektedir. Gilbert ile yakın ilişki kurar ve ona destek olur.

Filmin geçtiği yer olan Endora'nın, Amerika Birleşik Devletleri'nde küçük bir kasaba olup nüfusunun az, sosyal hayatının durgun olduğunu ve bu kasabada genç nüfusun azınlıkta olduğunu söylemek mümkündür. Her yıl belirli zamanlarda, insanlar karavanlarıyla Endora'ya gelip bir süre burada kalmaktadır. Grape ailesinin evinin kasaba merkezinin dışında olmasının ve kasabadaki sosyal hayatın durgun olmasının özellikle ergenlik döneminde olan Ellen ve hayatını tamamen Endora'da geçirmiş olan Gilbert için bir risk faktörü olduğunu söylemek mümkündür. Filmde Ellen'ın arkadaşlarıyla paylaştığı herhangi bir sosyal ortama yer verilmemektedir. Gilbert'in ise Bobby McBurney ve Tucker Van Dyke dışında arkadaşı olmadığı, zaman zaman onlarla birlikte yemek yediği görülmektedir. Ellen, Gilbert ve Amy için geçmiş yaşantıları (babanın intiharı, büyük erkek kardeş Larry'nin evi terk etmesi, annelerinin zamanla obezite hastası olması) ve Arnie'nin sürekli bakıma, ilgiye ve yakın takibe ihtiyaç duyması başlı başına risk faktörleridir. Aile içi rolleri sebebiyle bu karakterlerin gelişimsel süreçte kişisel hayatlarını şekillendirme fırsatı bulamadıkları görülmektedir. Süreç içinde Becky'nin ilgisi ve şefkati Gilbert açısından koruyucu bir faktöre dönüşmektedir. Gilbert, Becky sayesinde hem duygusal intiyaçlarını karşılamakta hem de Becky'nin sorunlara yönelik desteği sayesinde yaşadığı stres ve içinde bulunduğu zorluklarla daha iyi baş edebilmeyi öğrenmektedir.

\section{Karakterlerin Sağlık Psikolojisi Açısından Incelenmesi}

Babasının 17 yı önce ölmesi ve Larry adında bir erkek kardeşinin evi terk edip gitmesi üzerine ailesiyle ilgili birçok sorumluluk Gilbert Grape'in üstüne kalmıştır. Lamson's Grocery adında bir markette çalışmaktadır ve kardeşi Arnie'nin bakımı, evin ekonomik ihtiyaçlarının giderilmesi, tamirat işleri gibi sorumlulukları yerine getirmeye kendini adamıştır. Gilbert hayatını tümüyle ailesine adamak, kendi hayatı adına hiçbir şey yapamamış olmak ve Endora'dan hiç ayrılamamaktan kaynaklı çeşitli sorunlar yaşamaktadır. Gilbert kasaba şartlarından kaynaklı duygusal intiyaçlarını karşılamakta da zorluk çekmektedir. Evli olan Betty Carver'ın evine siparişlerini götürdüğü sırada onunla cinsel olarak yakınlaşmaktadır. Gilbert'in hayatını belki de en iyi özetleyen kişi Betty Carver'dır. Betty, Gilbert'in "Neden beni seçtin?" sorusuna “Çünkü her zaman burada olacağını biliyordum. Buradan asla gitmeyeceğini biliyordum." diye cevap vermektedir. Filmin ilerleyen kısımlarında Gilbert, Becky ile tanışır ve bu hayatının seyrini değiştirecek bir sürecin başlangıcıdır. Gilbert, Becky'nin "Kendin için, sadece kendin için ne istiyorsun?" sorusuna "iyi bir insan olmak istiyorum." şeklinde cevap verir. Gelişim psikolojisi açısından bakılacak olursa Erikson'un hayat boyu gelişim dönemlerinden bahsettiği Psikososyal Gelişim Kuramı'na göre Gilbert genç yetişkinlik dönemindedir. Bu dönem insanların aileden bağımsızlaşmaya başladığı, gelecek hedefleri ve hayalleri doğrultusunda yaşamına yön vermeye başladığı ve diğer insanlarla yakın ilişkiler kurduğu bir dönemdir. Eğer bunlar başarılamazsa yalnızlık kaygısı ve yalıtılmışlık gibi duygular ortaya çıkmaktadır (1). Fakat Gilbert akranları gibi kendi hayatını planlamak ya da yakın ilişkiler kurmak yerine evde baba rolünü üstlenmek zorunda kalmış ve omuzlarına büyük bir sorumluluk almıştır. Kendini tamamen geri plana atarak ailesi için büyük bir fedakarlıkta bulunmuştur. Bu durum üstünde büyük bir baskı oluşturmuştur ki film boyunca yüzünden gitmeyen mutsuz ve sıkılmış ifade ne kadar zorlandığının işareti olarak görülebilir. Zaman zaman ailesini terk etme düşünceleri olsa da onları bırakamamıştır. Monoton ve ağır şartlardaki hayatına heyecan ve değişiklik katma isteği ya da hissetmiş olabileceği yalnızlık 
anksiyetesinin Gilbert'ı evli bir kadın olan Betty Carver'la yasak ilişki yaşamaya ittiği düşünülebilir. Ailedeki diğer üyelerle iyi geçinse de Gilbert'ın kardeşi Ellen'la ilişkisi kopuk ve çatışmalıdır. Babasının ölümünden diğer aile üyeleri gibi Gilbert da etkilenmiştir. Arnie gibi babasının intiharının gerçekleştiği bodruma inmekten kaçınması bu durumun bir göstergesidir. Ayrıca annesini kıyıya vurmuş balinaya benzetmesi annesinin her şeyden kopuk, işlevselliği tamamen bozuk bir hayat yaşadığını ve çaresiz olduğunu düşündüğünü göstermektedir. Bu yüzden zaman zaman ona karşı suçlama, utanma (tersini söylese de) ve öfke gibi duygular hissettiği düşünülmektedir. Bununla birlikte annesinin aerobik kursuna gitmesini ve kardeşleri için iyi olabileceğini düşündüğü şeyleri istemesi ve bunları kendi hayallerinin üzerinde tutması Gilbert'ın ailesini ne kadar çok sevdiğini göstermektedir. Hayatı monoton bir şekilde devam ederken karavanla seyahate çıkan ve araçları arızalanan kampçılardan biri olan Becky'ye aşık olmuştur. $\mathrm{Bu}$ onun için değişim isteğine kapı aralayan bir dönüm noktasıdır. Becky'ye aşık olduktan sonra çok bunaldığı bir zaman diliminde evden kaçmış, fakat geri dönmüştür. Bu da Gilbert'daki değişim isteğinin bir ön hazırlığı gibidir. Ayrıca Becky'nin olumlu ve iyi kalpli olması, pek çok yeri gezip görmüş olması ve hala gezmeye devam etmesi de Gilbert'ı etkilemiştir. Özetle, babasının ölümü ve annesinin hayattan kopuk hale gelmesiyle birlikte Gilbert'ın üstüne büyük sorumluluk düşmüş ve bu durum ailesinin eski mutlu günlerine duyduğu özlemi de beraberinde getirmiştir. Ayrıca annesinin günden güne kilo alıp sağlığını kaybetmesi ve buna şahit olması da onu zorlayan durumlardan biri olmuştur. Becky ile tanıştıktan sonra aile içindeki sorumluluğu ve aşk arasında ikilem yaşamış, ailesi ve hayalleri arasında kalan bir genç yetişkine dönüşmüştür.

Arnie sürekli bakıma ve korunmaya ihtiyaç duyan bir karakterdir. Arnie'nin DSM-5 Tanı Ölçütleri doğrultusunda Nörogelişimsel Bozukluklar sınıflamasında bir psikopatolojisi olduğu (akt., 2) düşünülmekle birlikte filmden edinilen bilgiler doğrultusunda ayırıcı tanı yapabilmek oldukça zor görünmektedir. Bilindiği üzere OSB ve entelektüel yeti yitimi ayırıcı tanı konusunda üzerinde dikkatle durulması ve iyi değerlendirilmesi gereken iki psikopatolojidir. Arnie bu iki bozukluğa ilişkin birçok belirtiyi bir arada göstermekte ancak Arnie'nin bu iki psikopatolojiden hangisine sahip olduğu konusunda yeterince bilgi edinilememektedir. Çevresinde olan bitenlere yeterince ilgili görünmeme; amaçsız, yinelenen davranışlarda bulunma, stereotipik hareketlerde bulunma, konuşmada ekolali ve anlamsızlık (3), sınırlı sayıda davranış sergileme, alışılmamış törensel el hareketleri, müzik konusunda seçicilik, bilişsel becerilerde ağır ve ciddi yetersizliğe karşın kaba motor becerilerde ileri boyutlarda gelişim sağlanması (2) gibi OSB belirtileri Arnie'de görülmektedir. Anlamsız ve yineleyici el-kol hareketleri, Gilbert'in cümlelerini benzer tonlarda tekrarlaması, "Match in the gas tank, boom boom" gibi sınırlı sayıda şarkıya ilgi duyması ve bunları sürekli söylemesi, Endora su kulesinin merdivenlerinden kulenin tepesine ve evin önündeki ağaca sürekli tırmanması, saklambaç oyununu sürekli oynaması; aşırı duygulanımlar sırasında eliyle masaya vurma, kafasına vurma gibi davranışlar sergilemesi bu belirtilere örnek olarak gösterilebilir. Öte yandan, DSM-5 Tanı Ölçütleri doğrultusunda kavramsal alanda okuma, yazma ve sayısal becerilerde gerilik; sorun çözmede bakım verenlerinin yardımına muhtaç olma; toplumsal alanda sınırlı konuşma dili, toplumsal dışavurumunu tam olarak doğru algılayamama; uygulamalı alanda gündelik intiyaçlar (yemek yeme, giyinme, banyo yapma vb.) için desteğe gereksinim duyma, uyumsuz davranışlar, her zaman denetim altında olmayı gerektirme gibi entelektüel yeti yitimi belirtileri (2) de Arnie'de görülmektedir. Arnie'nin sayı sayarken "iki, üç, yedi, beş" şeklinde düzensizlikler sergilemesi; Gilbert tarafından yıkanması ve giydirilmesi, yine Gilbert tarafından sürekli gözetim altında 
tutulması, cenaze töreninde bağırarak uygunsuz davranışlar sergilemesi, "good bye ve goodnight" gibi cümleleri karıştırması; Gilbert'in Arnie'yi yıkarken ona artık kendisinin yıkanabileceğini söyleyerek onu yalnız bırakması ve ertesi sabah Arnie'yi halen banyoda bulması gibi durumlar örnek olarak gösterilebilir. Bütün bu değerlendirmenin yanı sıra literatürde bazı entelektüel yeti yitimi olgularında otizm belirtilerinin görülebileceğinden de bahsedilmektedir (3). Ek olarak, otizmli çoğu çocuğun standardize zekâ testlerinden 70'in altında puan aldıklarından da söz edilmektedir (2). Görüldüğü üzere OSB belirtilerine yüksek oranda entellektüel yeti yitimi de eşlik ettiğinden, Arnie karakterinin mevcut belirtilerle tanısı OSB'dir. Aile bağlarının güçlü olması; bakım verenlerin sabırlı, ilgili, sevecen ve sorumluluk sahibi olmaları; annenin duygusal paylaşımları vb. gibi faktörler Arnie açısından koruyucu faktörler olmakla birlikte özel eğitim alamaması, aile içi stresörler gibi faktörler ise risk faktörleridir.

Bonnie Grape 46 yaşında, sevecen, sabırlı, çekingen, anlayışlı özelliklere sahip bir anne olarak karşımıza çıkmaktadır. Gilbert'in "Zamanında bölgenin en güzel kadınıydı, zayıftı." diye tanımladığı Bonnie Grape için eşinin intiharı, yoğun bir depresyon örüntüsüne ve bu örüntünün obeziteye kadar gidecek olan bir dönemin başlangıcını tetiklemesine neden olmaktadır. Yedi yıldır evden dışarı çıkmayan Bonnie'nin gün içerisinde sürekli üzgün, çökkün duygudurum sergilediği; işlevselliğinin çok düşük düzeyde olduğu, günün hemen hemen tümünü aynı koltukta televizyon izleyerek ve yemek yiyerek geçirdiği görülmektedir.

Literatürde erişkinlerde obezitenin depresyondan daha önce görüldüğüne yer verilse de (4) Bonnie'nin yaşam olayları göz önünde bulundurulduğunda bu örüntünün tersine işlediği söylenebilir. Obeziteyi de içine alan yeme bozukluklarına çoğunlukla depresyon, kaygı bozuklukları ya da madde kullanımına ilişkin bozuklukların eşlik etmesiyle birlikte, obezitenin ortaya çıkmasında psikososyal, kültürel, duygusal, biyolojik veya ailesel faktörler rol oynamaktadır $(5,6)$. Yapılan bir çalışmada örneklemde yer alan obez hastaların çoğunda anksiyete ile giden uyum bozukluğu gibi çeşitli psikiyatrik sorunların var olduğu bildirilmektedir (7). Bir başka çalışmada ise obez kadınlarda depresyon riskinin obez olmayan kadınlara göre istatistiksel anlamda daha yüksek bulunduğu belirtilmektedir (8). Yine benzer şekilde, 16 araştırma üzerinde yapılan bir meta analiz çalışmasında karıştırıcı değişkenler kontrol altına alındıktan sonra depresyonda olan insanların depresyonda olmayanlara kıyasla obezite geliştirme açısından daha fazla risk altında olduklarından söz edilmektedir (9).

Literatürde ağır stresörler içeren olaylar karşısında insanların büyük ölçüde kilo aldıkları, gerilimden kurtulabilmek amacıyla yemek yeme davranışında aşırılığa kaçtıkları yönünde bilgiler mevcuttur (10). Bonnie Grape'in içinde bulunduğu ruhsal çöküntüyle birlikte işlevselliğini kaybettiği, hareketliliğinin kısıtlandığı, eşinin yokluğunda yeme davranışına yöneldiği ve bu doğrultuda obezite geliştirdiği olası bir senaryodur. Bir diğer olasılık ise Bonnie'nin Travma Sonrası Stres Bozukluğu (TSSB) geliştirdiğidir. Filmde Bonnie'nin Gilbert'in evi terk edip geri dönmesi üzerine "Lütfen ortadan kaybolma." demesi, yemekte eşinin ölümü üzerine yapılan konuşmada aşırı öfkeli ve dürtüsel davranışlar sergilemesi gibi durumlar TSSB'nin de göz önünde bulundurulması gerektiğini göstermektedir. Bonnie'nin eşini kaybetmesi sonucu uzun süren ve hala devam eden bir yas süreci içerisinde olduğu düşünülebilir. Yas durumlarında yaşanan üzüntü çoğunlukla beklendik kabul edilirken bazı kişilerde depresyon, kaygı gibi bozukluklar ortaya çıkabilmektedir (5).

Obezite, gelişmiş ve gelişmekte olan ülkelerde giderek artan bir sağlık sorunudur (10). Obezite hastaları çeşitli psikolojik sorunlar ile 
yüzleşmektedir (10-13). Bu sorunların ortaya çıkmasına katkıda bulunan önemli faktörlerden biri de obeziteye yönelik önyargılardır (11). Gordon Allport (14) "Önyargının Doğası" adlı kitabında önyargıyı hatalı ve esnek olmayan genellemelere dayalı, bir bireye ya da gruba yönelik antipati olarak tanımlamaktadır. Önyargılar tanımda bahsedilen antipatiyi desteklemeye yönelik bilişsel inanışlar olan kalıpyargılarla beslenebilmekte, zaman zaman bu kalıpyargı ve önyargıların davranışa dökülmesi neticesinde ise ayrımcılık ortaya çıkabilmektedir (15). Önyargılar din, cinsel yönelim, yaş, göçmenler, fiziksel görünüm vb. gibi birçok alana yönelik oluşturulabilir (15). Fiziksel görünüme ilişkin önyargılardan biri olan obeziteye yönelik önyargılara ilişkin çeşitli çalışmalar bulunmaktadır. Altun (12) tarafından yapılan, katılımcılar arasında Sağlık Bilimleri Fakültesi öğrencilerinin de bulunduğu, 732 katılımcının yer aldığı bir çalışmada katılımcıların $\% 55,1^{\prime} i$ önyargıya eğilimli, $\% 26,5^{\prime} i$ ise önyargılı olarak bulunmuştur. Merdol (16) tarafından 199 yetişkinle yapılan bir çalışmada katılımcıların obeziteye ilişkin önyargıları ölçülmüş; araştırmanın sonucunda katılımcıların $\% 50,8^{\prime} i$ önyargılı, \%47,7'si önyargıya eğilimli ve $\% 4,5^{\prime} i$ önyargısız olarak bulunmuştur. Ayrıca katılımcıların \%48,2'si obez olmayı "bir insanın yaşayabileceği en kötü şey" olarak değerlendirmişlerdir. Usta, Acar ve Aygin'in (11) Sağlık Hizmetleri Meslek Yüksekokulu'nda öğrenim görmekte olan 180 öğrenci ile yaptığı bir çalışmada katılımcıların \%72,3'ünün obez insanları çok sevmediği, \%60'ının obez bir bireyi karşı cins olarak çekici bulmadı̆̆ı, \%89,7'sinin ise obez bir bireyle evlenmeyi düşünmediği bulunmuştur. Yine aynı çalışmada katıımcılarla obez bireylerin kişilik özelliklerine yönelik yapılan ölçümlerde katılımcıların \%75,5'inin obez bireyleri sosyal olmayan, $\% 74,2$ 'sinin içe kapanık, \%70,3'ünün özgüvenleri düşük şeklinde tanımladıkları görülmüştür. Cihan (17) tarafından 145 katılımcı ile yapılan bir diğer çalışmada ise obez bireylerde damgalanma hissi araştırılmıştır. Katılımcıların \%39,3'ü çocuklukta öğretmenleri tarafından hayatlarında en az bir defa dışlandıklarını, \%46,9'u hayatlarında en az bir defa ağırlıklarından dolayı toplum içinde kaba sözlere maruz kaldığını, \%46,9'u toplum içinde kendileri hakkında kaba sözler söyleyenlere kulak misafiri olduklarını belirtmişlerdir. Bonnie Grape yapılan literatür çalışmalarıyla paralellik gösteren bir şekilde obeziteye ilişkin pek çok önyargıya maruz kalmakta, bu durum hayatını ciddi boyutlarda etkilemektedir. Toplumun bakış açısını tahmin etmekte zorlanmayan ve yaşadığı toplumsal baskıyı içselleştirerek hayatını bu doğrultuda şekillendirmek zorunda kalan Bonnie insanların kendisi hakkındaki olumsuz düşüncelerinden kaçmak için film boyunca topluma karışmaktan kaçınmakta ve çocuklarının kendisinden utandığına dair çarpık inançlar taşımaktadır. Arnie için düzenlenen partiye katılmadığı, Gilbert'a kendisinden utanıp utanmadığını sorduğu ve Gilbert kız arkadaşı ile tanıştırmak istediğinde isteksiz davrandığı sahnelerde buna bağlı davranışlarını açıkça görebilmekteyiz. Öte yandan Gilbert'in ideallerini gerçekleştirebilmesinin önünde duran engeller karşısında giderek tahammülünün azaldığı ve bu durumun sonucunda toplumsal damgalamanın bir parçası olmaya başladığı da göze çarpmaktadır. Gilbert'in Becky ile konuşması sırasında annesinden "karaya oturmuş bir balina" olarak bahsetmesi bu durumu örnekler niteliktedir. Bonnie karakoldan ayrıldığı sahnede kendisini görmek için toplanan bir grup insanın alaycı bakışlarına maruz kalmakta, bu durum onu daha da yıpratmaktadır. Bu şekilde bir yüzleşme yaşayan Bonnie'nin toplumun obeziteye bakış açısına yönelik fikirlerinin desteklendiğini görmesi onu bir ikileme sürüklemektedir. Bonnie içinde bulunduğu durumdan kurtulmaya yönelik adımlar atmak istemekte ancak toplumun baskısından kaçınmak istemesi bu durumu engellemektedir. Obeziteye yönelik önyargılar sağlık hizmetleri ortamında bile yaygın bir şekilde görülmekte; bu durum obez bireylerin 
sağlık hizmetlerinden yararlanmalarından kaçınmalarına, tedavilerini aksatmalarına ve gittikçe artan sağlık problemleri ile yüzleşmelerine neden olmaktadır (13). Sonuç olarak, obezite önyargısından dolayı evinden dışarı çıkmayan, sağlık hizmetlerinden kaçınan, tedavilerini aksatan ve giderek artan sağlık sorunları ile karşılaşan diğer obez bireyler gibi (13) anne Bonnie Grape'in de tedaviye yönelik adımlar atmak istese de yaşadığı baskı, maruz kaldığı önyargılar ve damgalanmanın etkisiyle sağlık hizmetleri almaya yönelik adım atamadığı, ruhsal bir bunalımın ortasına sürüklendiği görülmektedir.

Psikolojik faktörlerin yanı sıra, Bonnie'nin yaşam tarzı ve çevresel faktörler de obezite hastalığına katkıda bulunmaktadır. Bonnie'nin tüm gününü TV karşısında geçirmesine bağlı olarak fiziksel aktivite eksikliği gibi nedenler obezite hastalığı ile ilişkilendirilebilir (10). Ayrıca sürekli sağ|ıksız besinler tüketmesi ve aşırı yeme davranışı da obeziteye yol açan etmenler arasında gösterilebilir (6). Bonnie'nin yerinden hiç kalkmaması ve bu nedenle de tüm ev içi sorumlulukların ailenin diğer üyeleri tarafından üstlenilmesi fiziksel aktiviteyi düşürdüğü için obezite durumunu tetikleyen faktörler arasında yer almaktadır.

Üzerinde durulması gereken bir diğer konu Bonnie Grape'in filmin sonunda her zaman oturduğu koltuktan kalkarak üst kata çıkması ve yatağına uzandıktan kısa bir süre sonra hayatını kaybetmesidir. Bu ani ölümün arkasında akla gelen ilk sebep miyokard infarktüsüdür. Obezitenin koroner kalp hastalığıyla ilişkili olduğu bilinmektedir $(18,19)$. Dahası obeziteyle ilgili metabolik değişimlerin de koroner kalp hastalı̆̆ı risk artışına katkı sağladığı düşünülmektedir (18). Yapılan bir çalışmada miyokard infarktüsü semptomlarını düşündüren bir öykü sonucu ani ölüm olarak tanımlanan, semptom başlangıcından itibaren 24 saat içinde gelişerek ölümle sonuçlanan vakalar koroner kalp hastalığından kaynaklı ölümler olarak değerlendirilmiştir (19).

\section{Bonnie Karakteri Üzerinden Obezitenin Etiyolojisine Yönelik Kuramsal Bir Analiz}

Bonnie'nin obezite rahatsızlığı ve yemeğe bağımlı hali pek çok farklı kuram ile açıklanabilmektedir. Bu kuramlardan ilki pekiştirme kuramıdır. Pekiştirme kuramı açısından, anksiyete durumu sonucunda yemek yemenin verdiği rahatlık ve olumsuz duygulardan geçici bir süreliğine uzaklaşma ödül işlevi görüp davranışın pekiştirilmesine neden olmuş olabilir (6-10).

Bilişsel paradigma açısından bakıldığında yanlış inançlar ('yemek yemek beni rahatlatıyor' gibi), hatalı problem çözme davranışları örüntüsüne ya da yaşadığı travmatik olaylar bilişsel değişimlere yol açmış, benlik denetiminin bozulmasına neden olmuştur. Ogden ve Wardle (akt. 6) benlik denetiminde bozulma olduğunda kişinin yeme davranışı sanki kendi kontrolünde değilmiş gibi düşündüğünü, kişinin bu durum karşısında hiçbir şey yapmayıp edilgen bir tavır sergilediğini belirtmiştir. Herman ve Polivy (akt. 6) tarafından edilgen bir tavır sergilemek yenilginin kabul edilmesi ve vazgeçme olarak tanımlanmaktadır. Filmde de görüldüğü gibi Bonnie karakteri yeme karşısında kontrolünü kaybetmiş, boyun eğmiş, değişime kendisini kapatmış olarak algılanmaktadır. Kısıtlayıcı ve kontrolsüz bir biçimde yiyen kişilerle yapılan görüşmeler sonucunda bu kişilerin "Dürtülerime boyun eğeceğim. Uğraşamam, yemeyi bırakmak çok fazla çaba gerektiriyor." gibi edilgen bilişlere sahip oldukları ortaya çıkarılmıştır (6).

Filmde Bonnie'nin eşinin intiharından sonra evden çıkmayı reddedip kendini yemek yemeye vermesi obezite oluşumunda duygudurumun rolüne dair iyi bir örnek sunmaktadır. Emosyonel yeme psikolojik sıkıntı durumlarında bireyin yeme miktarının değişmesini ifade etmekte, emosyonel az yeme ve emosyonel çok yeme şeklinde iki alt tipi bulunmaktadır $(6,20)$. 
Emosyonel aşırı yeme stres ve olumsuz duygulara yiyecek alımı ile cevap verme eğilimidir ve bu durumun depresyon ve kilo alımı arasındaki ilişkide davranışsal aracı role sahip olduğu varsayılmaktadır (20). Bonnie'nin aşırı yeme davranışı olumsuz duygu durumunu kontrol edebilmesi açısından işlevseldir. Emosyonel yeme davranışı, olumsuz duygunun telafisinde önemli bir rol oynadığı için bugün obezite tedavisinde psikososyal etmenler de dahil edilerek davranış terapileri uygulanmaktadır (20). Böylece bu görüşe göre sadece fiziksel semptomlar değil bu semptomlara neden olan psikolojik faktörler de tedaviye dahil edilmelidir.

Bonnie'nin aşırı yeme davranışını açıklayabilecek bir başka yaklaşım ise yeme davranışııın nedensel analizidir. Bu ilginç yaklaşım ilk olarak Herman ve Polivy (akt. 6) tarafından tanımlanmıştır. Polivy ve Herman'a göre diyet yapmak ve tıkanırcasına yemek nedensel olarak bağlantılıdır ve kısıtlama aşırı yemekten önce gelmekle birlikte aynı zamanda buna nedensel olarak da katkıda bulunmaktadır (6). Gençken kasabanın en güzel kızlarından olan Bonnie, güzel fiziğini yaptığı diyet sonucu elde etmiş olabilir. Sonrasında yaşadığı travmatik olaylar önceden yaptığı diyet çabalarının ve kısıtlamanın gün yüzüne çıkıp aşırı yeme davranışına dönüşmesine sebebiyet vermiştir. Fakat filmde sadece Bonnie'nin güzel bir kız olduğundan bahsedilip diyetle ilgili bir şey belirtilmediği için bu sadece bir varsayım olarak kalmaktadır.

Öz belirleme kuramı ise güdülere (içsel ve dışsal güdüler) odaklanmakta ve bunların davranış üzerinde etkili olduğunu belirtmektedir (6) Bu kuram açısından değerlendirildiğinde Bonnie'nin aşırı yeme ve sigara içme davranışı üzerinde rahatsız edici duygulardan kaçınma gibi bazı içsel güdüleri etkili olmuştur. Bu içsel güdüleri ortaya çıkaran yeterlik ("Çevremi kontrol edebilirim.") gibi ihtiyaçlar bulunmaktadır ki Bonnie'nin filmdeki emredici ve eleştirel tavrı bu ihtiyacına örnek oluşturmaktadır. Dış görünüşünden dolayı çevresinde alay konusu olması ve bu nedenle dışarı çıkmaması da sürekli evde kalma davranışına neden olan dışsal güdülenmeyi göstermektedir.

Illk kez Bandura'nın Sosyal Öğrenme Kuramı́nın bir parçası olarak kullandığı öz yeterlik kavramı insanın ilerde karşılaşacağı durumları idare edebilmek için gereken hamlelerin kaynaklarını düzenleyip hayata geçirebilme yolunda kendi kapasitesine olan inancı olarak tanımlanmış (6) ve yeme davranışı ve egzersiz gibi pek çok davranışı açıklamak için kullanılmıştır (6). Bonnie'nin “Dengeli beslenmeye başlayabilirim, spora başlayabilirim, iyileşebilirim..." şeklinde inançlarının olmaması onun öz yeterliğinin düşük olduğunu ve yeteneklerine güvenmediğini göstermektedir.

Bireyler olayların nedenlerine yönelik çeşitli algılara sahiptir ve genellikle olayların nedenlerine yönelik çıkarımlarda bulunurlar. Bu durum "atıf kuramı" olarak adlandırımaktadır. Bu kurama göre insanların davranışları olaylara yönelik çıkarımlarına ve nedenlerine göre şekillenmektedir (6). Atıf kuramı açısından bakıldığında bireylerin davranışlarının nedenlerine dair yaptıkları atıflar hastalığın gidişatı hakkında fikir verebilmektedir. Bonnie'nin görüntüsünü kastederek kurduğu "Böyle olmayı asla ama asla istemedim." cümlesi obez hale gelişinde kendisinin bir rolü olmadığını, kendi kontrolü dışında bu hale geldiğini düşündüğünü, yani bir nevi dışsal atıfta bulunduğunu göstermektedir. Bonnie'nin Gilbert'ın kız arkadaşıyla yaptığı konuşmadan sonra, iç kontrol odağına yönelmesi sonucu hastalığıyla baş etmede ciddi bir adım attığı ve yıllar sonra ilk kez merdivenleri çıkıp kendi yatağında uyuduğu görülmektedir.

\section{Obezite Tedavisine Yönelik Farklı Bir Perspektif: Bonnie Karakterinin Değişim Aşamaları Modeli Açısından Analizi}

Prochaska ve Diclemente $(6,21)$ tarafindan geliştirilen Değişim Aşamaları (Transteoretik) 
modelde bireylerin davranış değişiminin niyet öncesi, niyet, hazırlık, eylem ve sürdürme olarak beş aşamadan oluştuğu, başarılı bir sonuç elde edebilmek için bireylerin içinde bulundukları aşamalara özel uygulamalara gereksinim duydukları belirtilmiştir.

Modelin ilk aşaması olan niyet öncesi dönem açısından değerlendirildiğinde Bonnie'nin eşinin ölümüyle birlikte yemek yemeye başlayıp obez hale geldikten sonra uzun yıllar bu aşamada kaldığı, herhangi bir değişim teşebbüsünde bulunmadığı, sürekli yemekten mutluymuş gibi bir hali olduğu görülmektedir. Obezitenin tedavisinin uzun yıllardır geleneksel ve modern birçok yöntem ile mümkün (6) olmasına rağmen filmdeki Bonnie karakterinde sağlıklı bir yaşam için herhangi bir niyet belirtisi görülmemektedir. Bonnie'yi bu bağlamda Değişim Aşamaları Modeli'nde (21) "niyet öncesi dönem" içerisine dâhil etmek mümkündür. Ancak filmin ilerleyen kısımlarında Bonnie'nin yaşadığı olaylar sonucunda harekete geçmesi bir diğer dönem olan "niyet" döneminin özelliklerini taşımaya başladığına işaret etmektedir. Bonnie Arnie'nin hapse atıldığını öğrendiğinde yıllar sonra ilk kez evden çıkar ve oğlunu kurtarmak için karakola gider. Karakoldan çıktığında kendisini görmek için meydanda toplanan kasabalıların alaycı bakışlarına maruz kalır ve muhtemelen ilk kez kilosundan rahatsızlık duymaya başlar. Yaşadığı bu olay Bonnie'yi içerisinde bulunduğu durumu değerlendirmeye ve bu durumu düzeltmeye yönelik adımlar atmaya yönlendirmektedir. Artık Bonnie'nin Değişim Aşamaları Modeli'nin bir diğer aşaması olan "hazırlık" aşamasına geçmeye başladığı görülmektedir. Bonnie kasabalıların alaycı bakışlarına maruz kalmasından sonra ilk kez akşam yemeğinde hiçbir şey yemeden oturur. Bu muhtemelen artık yemeyi azaltacağı ve kilo vermeye başlayacağı hissini uyandırmaktadır. Ancak birkaç sahne sonra Bonnie yine elinde cipsle televizyon izlerken görülür. Bu da Eylem ve Koruma aşamalarına gelemeden tekrar Niyet öncesi döneme döndüğünü düşündürmektedir. Filmin sonuna doğru Arnie'nin 18. yaş gününü çocukların alay konusu olmaktan çekindiği için pencereden izler ve hemen ardından Gilbert'ın kız arkadaşıyla yaptığı konuşmanın da etkisiyle doğum günü gecesi merdivenleri çıkıp yatağında uyumaya karar verir. Böylece tekrar hazırlık aşamasına geçtiği görülmektedir. Ancak Bonnie tüm aşamaları tamamlayamadan ölür.

Bütün bunların yanı sıra obezite sonrası yaşanabilecek psikolojik faktörler olan özsaygı, benlik algısında düşüklük gibi psikolojik faktörler de Bonnie'nin değişime isteksizliğinin nedenlerinden biri olabilir. Ayrıca ailesi tarafından gerek tedavi sürecine atılma gerekse psikolojik iyi oluş açısından çok destek görmemesi de -filmde çocukların, annelerinin sağlıksız besinler yemesini önleme ya da egzersiz için motive etme gibi davranışlarda bulunmadığı gözlemlenmektedir- obezite sürecinin seyrinde önemli bir etkendir. Bunlara ilave olarak ailenin gelir düzeyinin yeterli olmamasının ve yaşadıkları yerin küçük bir kasaba olmasının da Bonnie'nin gerekli sağlık hizmetlerine ulaşmasında engelleyici bir rol oynadığı düşünülmektedir.

Bozdağ (22) "What's Eating Gilbert Grape?" filmini sistemik olarak aile terapileri açısından ele almış ve ailedeki sorunların nasıl birbirleriyle etkileşim içinde olduğunu ortaya koymuştur. Bu film analizinde ise bir ailenin yaşadığı problemlerin sağlık psikolojisi kavramıyla ele alınması hedeflenmiştir. Filmdeki bireylerin yaşadığı obezite, OSB, entelektüel yeti yitimi gibi psikolojik sağlık sorunlarının karakterler üzerinde etkisi anlatılmıştır. Filmdeki örneklerden yararlanılarak bu rahatsızlıkların etiyolojileri, gelişimi, insan hayatı üzerindeki etkileri ele alınmıştır. Filmde yer alan kavramların sağlık psikolojisi kavram ve kuramları açısından ele alınmasının, örneklerle anlatılmasının bu kavramları daha anlaşılır hale getireceği düşünülmektedir. Bu çalışma sağlık psikolojisi kavramlarının açıklanmasında örneklerin yetersiz olduğu durumlarda okuyucuya detaylı bilgi sağlamada, 
rahatsızlıkların seyri ve etiyolojisinin daha iyi anlaşılmasında, aile içerisinde psikolojik rahatsızıkların ne gibi etkileri olduğunun anlaşılmasında literatüre katkı sağlamayı hedeflemektedir.

\section{Bilgilendirilmiş Onam: Gerekmemektedir.}

Çıkar Çatışması: Yazarlar çıkar çatışması beyan etmemişlerdir.

Finansal Destek: Yazarlar finansal destek beyan etmemişlerdir.

\section{KAYNAKÇA}

1. Myers DG. Sosyal psikoloji. 10. Baskı. (Çeviri Eds S Akfırat). Ankara, Nobel Yayıncılık, (Orijinal çalışma basım tarihi 2010) 2019.

2. Kring AM, Johnson SL. Anormal Psikolojisi (Çeviri Eds M Şahin). Ankara, Nobel Akademik Yayıncılık, 2017.

3. Öztürk MÖ, Uluşahin NA Ruh sağlığı ve bozuklukları. 15. Baskı. Ankara, Nobel Tıp Kitabevleri, 2018.

4. Balcıoğlu İ, Başer SZ. Obezitenin psikiyatrik yönü. i̇.Ü. Cerrahpaşa Tıp Fakültesi Sürekli Tıp Eğitimi Etkinlikleri Sempozyum Dizisi 2008; 62.

5. Nevid JS, Rathus SA, Greene B. Değişen dünyada anormal psikolojisi (Çeviri Eds. A D Batıgün) 2020.

6. Ogden J. Sağlık Psikolojisi. 5.Baskı. (Çeviri Eds G Dirik). Ankara, Nobel Akademik Yayıncılık, 2019.

7. Değirmenci T. Obez erişkinlerde benlik saygısı, yasam kalitesi, yeme tutumu, depresyon ve anksiyete (Yayınlanmamış Uzmanlık Tezi). Denizli, Pamukkale Üniversitesi, 2006.

8. Çakmur H, Güneş ÜB. Poliklinik başvurularında obezite ve depresyon ilişkisinin incelenmesi. Türkiye Aile Hekimliği Dergisi 2018; 22(2): 58-65.

9. Blaine B. Does depression cause obesity? A metaanalysis of longitudinal studies of depression and weight control. Journal of Health Psychology 2008; 13(89): 1190-1197.

10. Altunkaynak BZ, Özbek E. Obezite: Nedenleri ve tedavi seçenekleri. Van Tıp Dergisi 2006; 13(4): 138-142.

11. Usta E, Acar K, Aygin D. Sağlık Hizmetleri Meslek Yüksekokulu öğrencilerinin obeziteye ilişkin tutumları [UMYOS Özel Sayısı]. Electronic Journal of Vocational Colleges, 2015; (4): 46-53.

12. Altun S. Üniversite öğrencilerinin obeziteye ilişkin önyargılarının belirlenmesi (Yayınlanmamış yüksek lisans tezi). Ankara, Başkent Üniversitesi, 2015.

13. Altun $S$, Ercan A. Obezite önyargısı. Türkiye Klinikleri Beslenme ve Diyetetik 2016; 2(1): 17-22.

14. Allport GW. The nature of prejudice, (4th ed.). Canada: Addison-Wesley Publishing 1966.

15. Taylor SE, Peplau LA, Sears DO. Sosyal psikoloji. 4.
Baskı. (Çeviri Eds A Dönmez). Ankara, İmge Kitabevi Yayınları, 2015.

16. Merdol DS. Yetişkin bireylerde obezite önyargısı ile yaşam kalitesi ve beslenme durumları arasındaki ilişkinin değerlendirilmesi (Yayınlanmamış yüksek lisans tezi). Ankara, Başkent Üniversitesi, 2019.

17. Cihan, G. Obez bireylerde damgalanma hissi ile yeme davranışları ve depresyon arasındaki ilişkinin incelenmesi (Yayınlanmamış yüksek lisans tezi). Ankara, Başkent Üniversitesi, 2019.

18. Helvacı A, Tipi FF, Belen E. Obeziteye bağlı kardiyovasküler hastalıklar. Okmeydanı Tıp Dergisi 2014; 30(Ek sayı 1): 5-14.

19. Badıllığlu O, Toğrul ZÜ, Uçku ŞR. İzmir, Güzelbahçe'de koroner kalp hastalığı beş yıllık insidansı ve risk faktörleri ile ilişkisi. Türkiye Halk Sağlığı Dergisi 2011; 9(3): 129-132.

20. Annesi JJ. Relationship of Emotional Eating and Mood Changes Through Self-Regulation Within Three Behavioral Treatments for Obesity. Psychological Reports 2018 doi:10.1177/0033294118795883

21. Prochaska JO, DiClemente CC. Transtheoretical therapy: Toward a more integrative model of change. Psychotherapy: Theory, Research \& Practice, 1982; 19(3): 276288.

22. Bozdağ Y. Film Analizi Yöntemi ille Aile Terapileri: Gilbert'in Hayalleri. Yaşam Becerileri Psikoloji Dergisi 2018; 2(3): 87-95. 